\title{
Retratos de desaparecidos no Espaço de Memória e Direitos Humanos/ESMA, Argentina
}

\author{
Portraits of missing persons in the Memory and Human Rights \\ Space/ESMA, Argentina \\ Retratos de desaparecidos en el Espacio de Memoria y Derechos \\ Humanos/ESMA, Argentina
}

\author{
Katia Helena Rodrigues Dias ${ }^{1}$ \\ Francisca Ferreira Michelon²
}

\begin{abstract}
Resumo
O regime político ditatorial, que emergiu na América Latina a partir da década de 1960, foi caracterizado por uma postura autoritária e de significativas violações aos direitos humanos. Para conseguir seus objetivos e aniquilar o suposto inimigo, foi utilizado recursos ortodoxos militares, como, por exemplo, tortura física e psicológica. Para essas práticas, eram necessários locais onde centenas de milhares de pessoas em condições subhumanas estiveram em cativeiro, sendo que a maioria desapareceu nessas circunstâncias. Esses lugares ficaram conhecidos como Centros Clandestinos de Detenção, Tortura e Extermínio (CCDTE), e na atualidade alguns foram ressignificados como Espaços de Memória e Direitos Humanos. Na Argentina, durante a última ditadura civil-militar (1976-1983), um dos mais emblemáticos é onde funcionou a Escola de Mecânica Armada (ESMA). As desaparições ocorridas durante esse período, hoje se fazem presentes pela imagem dos desaparecidos. As imagens, portanto, são enunciativas do desaparecimento e sua história. Convergem para o discurso de uma vida interrompida e das razões políticas que levaram a isso. De forma simbólica, essas fotografias tem o desejo de que a memória desse passado recente não se esmaeça com o tempo, evocam o "não esquecimento". O espaço de memória imprime, por meio da sua visualidade, um sentimento dúbio do que se vê e do que não pode ser visto, do que é e do que era e foi ocultado. É o sentimento imanente da presentificação da ausência.
\end{abstract}

Palavras-chave: retratos de desaparecidos; Espaço de Memória e Direitos Humanos; ESMA; ditadura civilmilitar Argentina; fotografia; memória.

\section{Resumen}

El régimen político dictatorial, que surgió en América Latina a partir de la década de 1960, fue caracterizado por una postura autoritaria y de significativas violaciones a los derechos humanos. Para alcanzar sus objetivos y aniquilar al supesto enemigo, se utilizaron recursos ortodoxos militares, como, por ejemplo, tortura física y psicológica. Para esas prácticas, eran necesarios lugares donde cientos de miles de personas en condiciones subhumanas estuvieron en cautiverio, siendo que la mayoría desapareció en esas circunstancias. Esos lugares quedaron conocidos como Centros Clandestinos de Detención, Tortura y Exterminio (CCDTyE), y en la actualidad algunos fueron resignificados como Espacios de Memoria y Derechos Humanos. En Argentina, durante la última dictadura cívico-militar (1976-1983), uno de los más emblemáticos es donde funcionó la Escuela de Mecánica Armada (ESMA). Las desapariciones ocurridas durante ese período, hoy se hacen presentes por la imagen de los desaparecidos. Las imágenes, por lo tanto, son enunciativas de la desaparición y su historia. Convergen para el discurso de una vida interrumpida y de las razones políticas que llevaron a eso. De forma simbólica, esas fotografías tienen el deseo de que la memoria de ese pasado reciente no se desvanece con

\footnotetext{
${ }^{1}$ Doutoranda em Memória Social e Patrimônio Cultural; UFPEL; Pelotas; RS; Brasil; dias.k.helena@ gmail.com

${ }^{2}$ Doutora em História pela Pontifícia Universidade Católica do Rio Grande do Sul; Porto Alegre. Doutora em Memória Social e Patrimônio Cultural; UFPEL; Pelotas; RS; Brasil; fmichelon.ufpel@gmail.com
} 
el tiempo, evocan el "no olvido". El espacio de memoria imprime, por medio de su visualidad, un sentimiento dudoso de lo que se ve y de lo que no puede ser visto, de lo que es y de lo que era y fue ocultado. Es el sentimiento inmanente de la presentificación de la ausencia.

Palabras clave: retratos de desaparecidos; Espacio de memoria y Derechos Humanos; ESMA; dictadura cívicomilitar Argentina; fotografía; memoria.

\begin{abstract}
The dictatorial political regime, that emerged in Latin America from the 1960s, was characterized by an authoritarian stance and significant violations of human rights. To achieve its objectives and to annihilate the supposed enemy, military orthodox resources were used, such as physical and psychological torture. These practices required places where hundreds of thousands of people in subhuman conditions were in captivity, most of whom disappeared in these circumstances. These places became known as Clandestine Detention, Torture and Extermination Centers (CCDTE), and at present some have been renamed as Memory Spaces and Human Rights. In Argentina, during the last civil-military dictatorship (1976-1983), one of the most emblematic is where the School of Armed Mechanics (ESMA). The disappearances that occurred during this period are now present in the image of the disappeared. The images, therefore, are enunciativas of the disappearance and its history. They converge to the discourse of an interrupted life and the political reasons that led to it. Symbolically, these photographs have the desire that the memory of this recent past does not fade with time, evoke the "nonforgetting". The space of memory imprints, through its visuality, a dubious feeling of what is seen and what can not be seen, of what is and what was and was concealed. It is the immanent feeling of the presentiment of absence.
\end{abstract}

Keywords: portraits of the disappeared; Space of Memory and Human Rights; ESMA; civil-military dictatorship Argentina; photography; memory.

\title{
1.Considerações iniciais
}

O regime político ditatorial conduzido pelos militares e consolidado com o apoio de alguns setores da sociedade civil, que emergiu na América Latina durante as décadas de 1960 e 1970, foi caracterizado por sua conduta hostil e violenta contra seus opositores políticos. No cone sul da América, o governo militar de países como a Argentina, Brasil, Chile e Uruguai teve como conduta rotineira perseguições, apreensões, torturas e desaparições massivas de pessoas, na maioria jovens, que protestavam e lutavam contra a tomada de poder imposta pela força. Essas pessoas, segundo a concepção autoritária de tais governos, representavam grande perigo à sociedade, por estarem aliados aos ideais comunistas e revolucionários que ganhavam força no contexto mundial daquele momento.

Sobre esses países, estabeleceu-se, por um longo período, uma política de austeridade e medo. A conduta radical do governo militar levou a cabo uma sistemática ação de controle e censura da população em geral. Para conseguir seus objetivos e aniquilar o suposto inimigo, eles utilizavam de recursos ortodoxos militares, como, por exemplo, tortura física e psicológica com o intuito de extrair informações de movimentos contrários a eles. E para a realização dessas práticas eram necessários locais onde centenas de milhares de pessoas em condições sub-humanas estiveram em cativeiro. 
$\mathrm{Na}$ Argentina, esses lugares ficaram conhecidos como Centros Clandestinos de Detenção, Tortura e Extermínio (CCDTE) e na atualidade alguns foram ressignificados como espaços de memória. Entre os espaços de memória, um dos mais significativos e emblemáticos é onde funcionou a Escuela de Mecánica de la Armada (ESMA). Esse local serviu como um dos maiores cativeiros humanos durante a última ditadura civil-militar Argentina. Estima-se que por lá estiveram aprisionadas cerca de 5 mil pessoas, das quais apenas cem sobreviveram. Em 24 de março de 2004, data que marca 28 anos do início desse regime político, foi inaugurado no local, o Espaço de Memória e Direitos Humanos, que recebe continuamente visita de escolas, pesquisadores e público em geral. (Figuras 1 e 2).

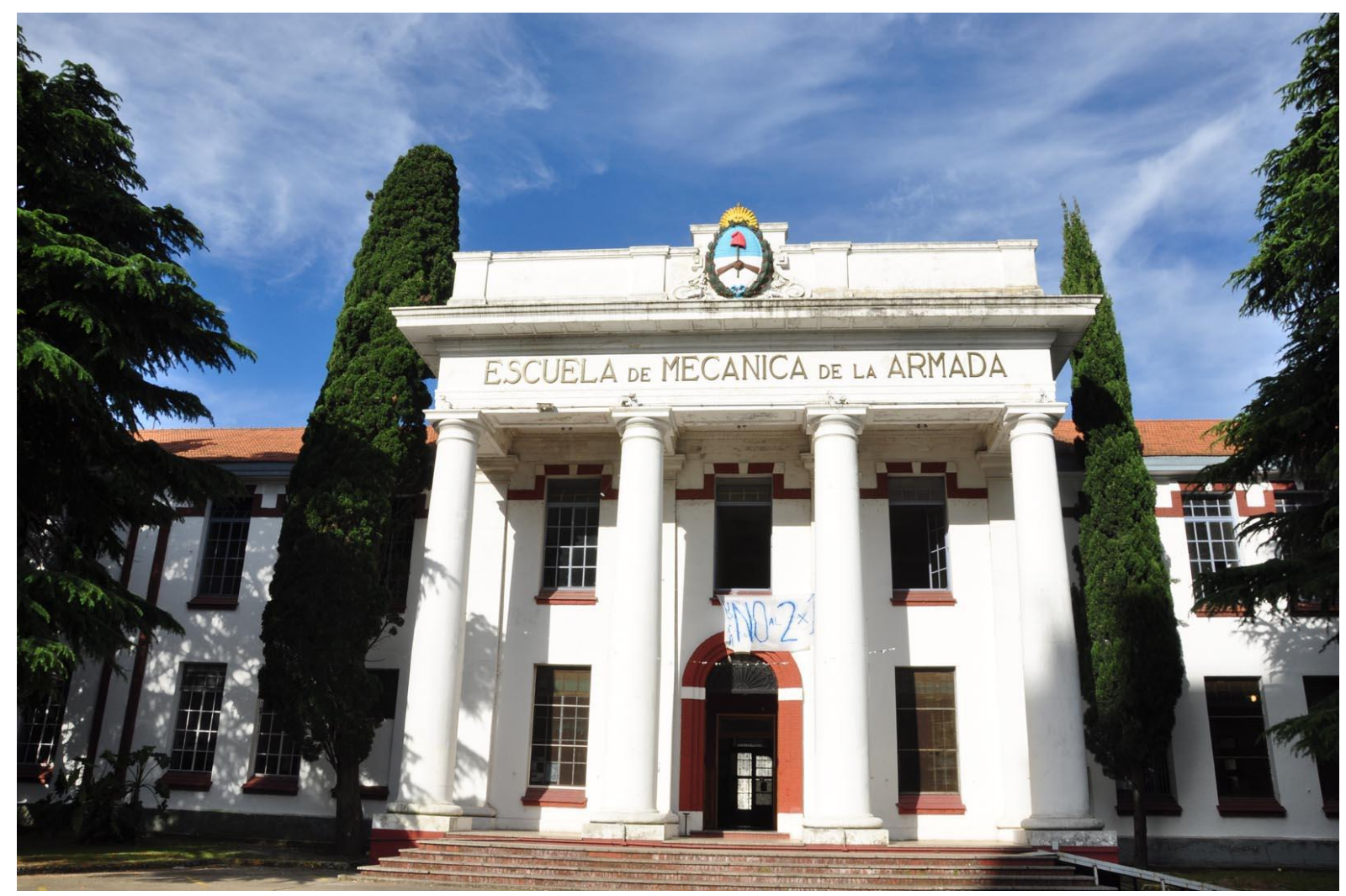

Figura 1 - Fachada do pavilhão das 4 colunas na ESMA. Fonte: fotografia do autor, 2017. 


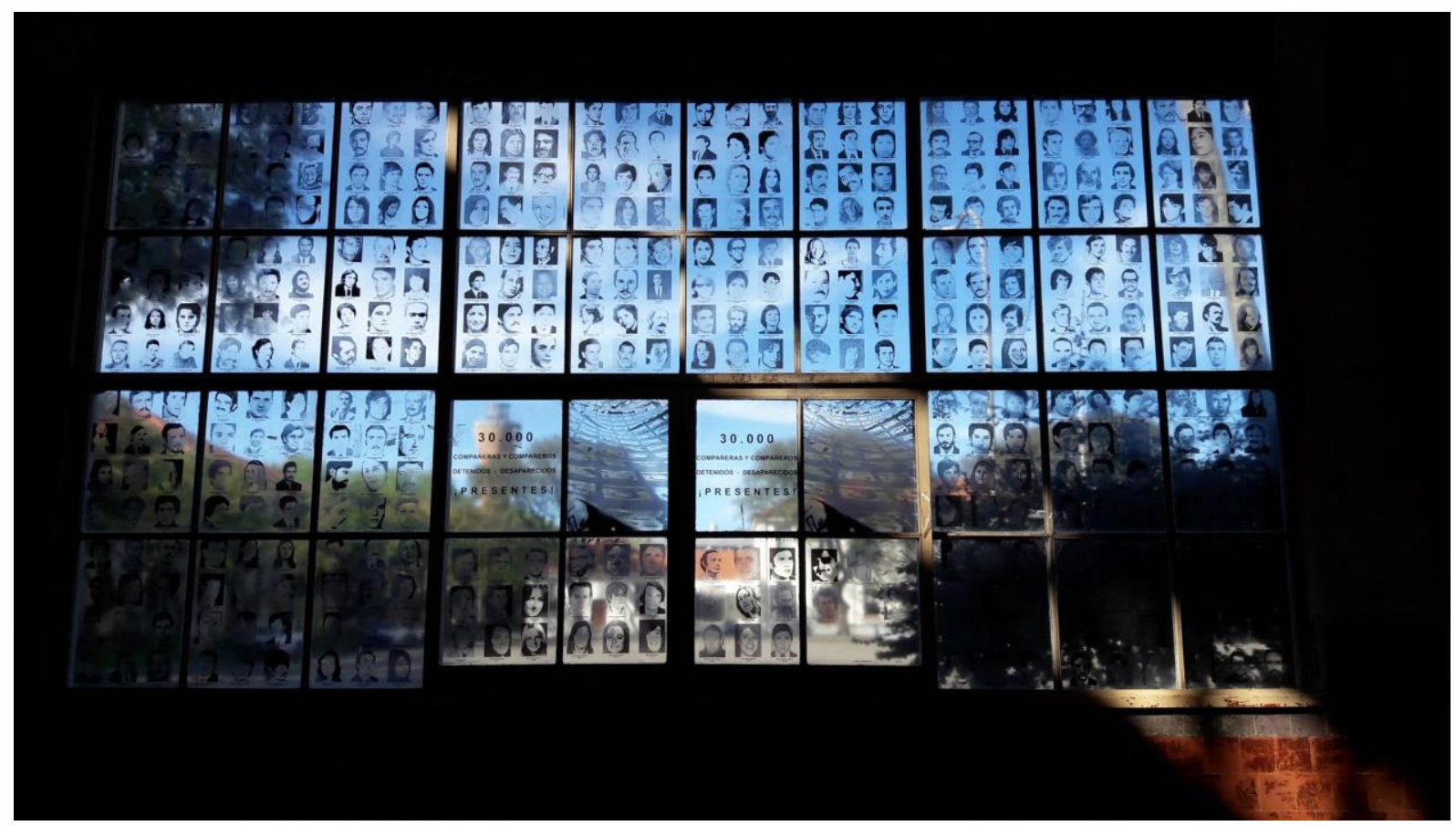

Figura 2 - Janela com retratos de desaparecidos. Fonte: fotografia do autor, 2017.

Ocupando uma ampla área, o local abriga diversos prédios de instituições ligadas à preservação e promoção da memória desse passado recente da Argentina. São arquivos, museus, centro cultural e órgãos destinados à promoção do debate, reflexão e fomento à pesquisa e constituição de conhecimento sobre questões referentes ao traumático período dessa história recente. Essas instituições, resguardadas suas especificidades, dialogam entre si e convergem para um mesmo ponto, o propósito comum de preservar a memória desse passado, inspirados pelo desejo de que nunca mais crimes de lesa-humanidade voltem a acontecer. O lema geral que permeia o lugar é: memória, verdade e justiça.

Este artigo se propõe a refletir sobre as fotografias de desaparecidos políticos expostas na ESMA. O ponto de partida da reflexão foi a pesquisa de campo realizada no local, registrada em um levantamento fotográfico que buscou identificar padrões nas imagens expostas e observar os modos de apresentação e a disposição pelo espaço e, identificar, os elementos que poderiam indicar um discurso sobre o sofrimento, a injustiça e a inumanidade.

Nesse aspecto, (DAVALLON,1992) expressa como os museus e espaços de memória são fundamentais ao operar, por intermédio de recursos expográficos e variados suportes, temas relacionados a memórias traumáticas e, assim, transformar o trauma em práticas discursivas, compartilhadas com o visitante. Como observam Ferreira; Michelon, (2015, p.81) "entende-se a fotografia como uma prática discursiva que, no lugar museu (instituição de memória), instala-se como cicatriz: uma marca de sofrimento.”. 
No contexto do levantamento, dá-se destaque às fotos do operário gráfico Víctor Basterra, um dos poucos sobreviventes do local. Sequestrado no ano de 1979, foi levado a ESMA e lá permaneceu até 1983. No cativeiro, passou a desempenhar tarefas no setor de documentação, como fotografar e identificar os presos políticos que ingressavam no local, assim como fotografar os oficiais militares (Figuras 3 e 4). A partir de um dado momento, Basterra começou de forma muito discreta a fazer cópias desses retratos e escondê-las. E quando começou a liberação parcial dos detentos, conseguiu levá-las escondidas entre suas roupas para fora das dependências da ESMA. Esses retratos, posteriormente foram de fundamental importância para o reconhecimento dos algozes e das vítimas desaparecidas e nunca encontradas. $\mathrm{O}$ destaque dado a essas imagens está na no modo como foram produzidas e guardadas, pelo fato de serem retratos para documentos que registram, o retratado em posição frontal e, portanto, de fácil identificação.
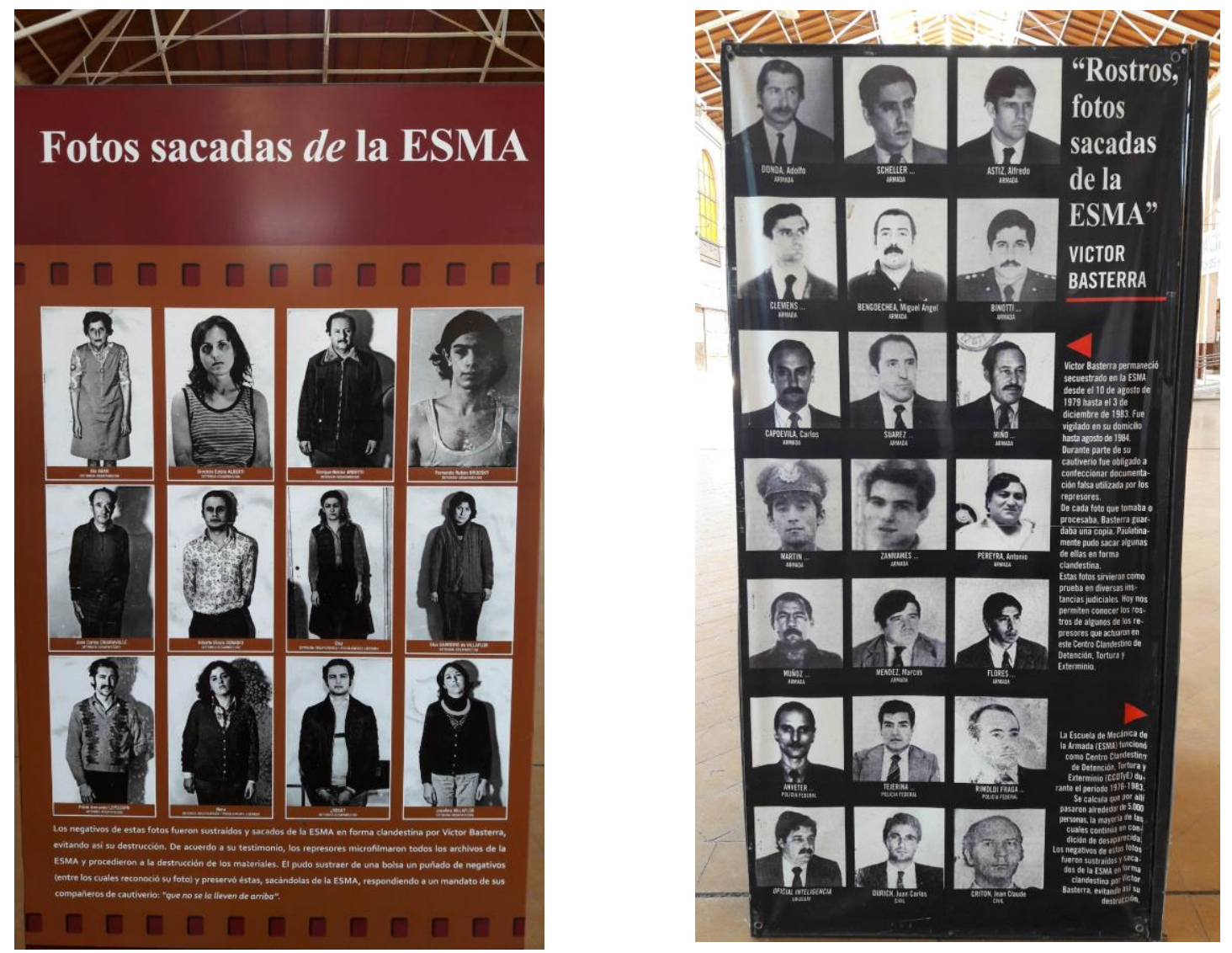

Figura 3 e 4 - Cartazes expostos na ESMA. Fonte: fotografia do autor, 2017. 


\section{A ausência presentificada}

"Isso foi" é a expressão que estabelece o noema barthesiano e que aponta a essência do punctum fotográfico (BARTHES, 1984). O passado imposto pela fotografia é a centralidade que se pretende usar como o elemento definidor da recorrência do uso de retratos de desaparecidos e mortos políticos em exposições de instituições de memória e de direitos humanos. A ESMA é o campo onde se observou a recorrência do efeito dual presença/ausência que essas fotografias provocam.

Os retratos de desaparecidos políticos estão dispostos por toda a extensão da ESMA e são apresentados em diferentes suportes e tamanhos. Essas imagens são provenientes e fazem parte de acervos de órgãos ali situados, como, por exemplo, o Archivo Nacional de la Memoria, vinculado à Secretaría de Derechos Humanos y Pluralismo Cultural do Ministerio da Justicia y Derechos Humanos, que tem como objetivo preservar e difundir os fundos documentais relativos a história recente e violações de direitos humanos e o Memoria Abierta, pertencente a uma rede de organizações de Direitos Humanos Latino-Americanos, que promovem a memória sobre os crimes cometidos durante o referido terrorismo de Estado. Ambas instituições funcionam como base de consulta e também destinam parte de seu espaço físico a expor o tema.

As imagens fotográficas, ali apresentadas e expostas são em sua maioria retratos de desaparecidos políticos que estiveram presos no local e o objeto desse estudo é o gênero retrato fotográfico. No entanto, cabe destacar brevemente a presença de outros tipos fotografias ali presentes. Como por exemplo, as produzidas por repórteres fotográficos, que conseguiram registrar manifestações, conflitos entre população e soldados militares, atos de perseguições e aprisionamentos em via pública e outros eventos característicos do regime ditatorial vigente naqueles anos. Grande parte dessas imagens foram censuradas e permaneceram, por muito tempo, invisíveis. Após o término da ditadura civil-militar, ganharam visibilidade nacional.

Na ESMA, assim como em outros lugares de memória similares, a apresentação da imagem fotográfica ligada à violência de Estado se constitui em ato discursivo e participa da eloquência do discurso que se formula no lugar. No entanto, o esforço de análise que se empreende no texto considera, especificamente, os retratos obtidos no próprio cativeiro e resgatados por um dos sobreviventes da ESMA, Victor Basterra, mencionado acima. O presente estudo leva em conta o relato de Basterra contido na base de arquivos orais do 
Memoria Abierta ${ }^{3}$. O depoimento de Basterra, longo e detalhado, constitui um importante conjunto documental sobre a ESMA uma vez que vem acompanhado das fotos que o detento conseguiu retirar do local.

Ao entrar no perímetro da ESMA, ao caminhar pelas ruas do espaço, ao participar das visitas guiadas ou ao pesquisar nas bases de dados dos arquivos ali situados, o visitante toma conhecimento da história de vida dos desaparecidos. O observador pode sentir-se também observado pelos olhares dos rostos inanimados ali presentes e representados pela imagem fotográfica. (Figuras 5 e 6 )

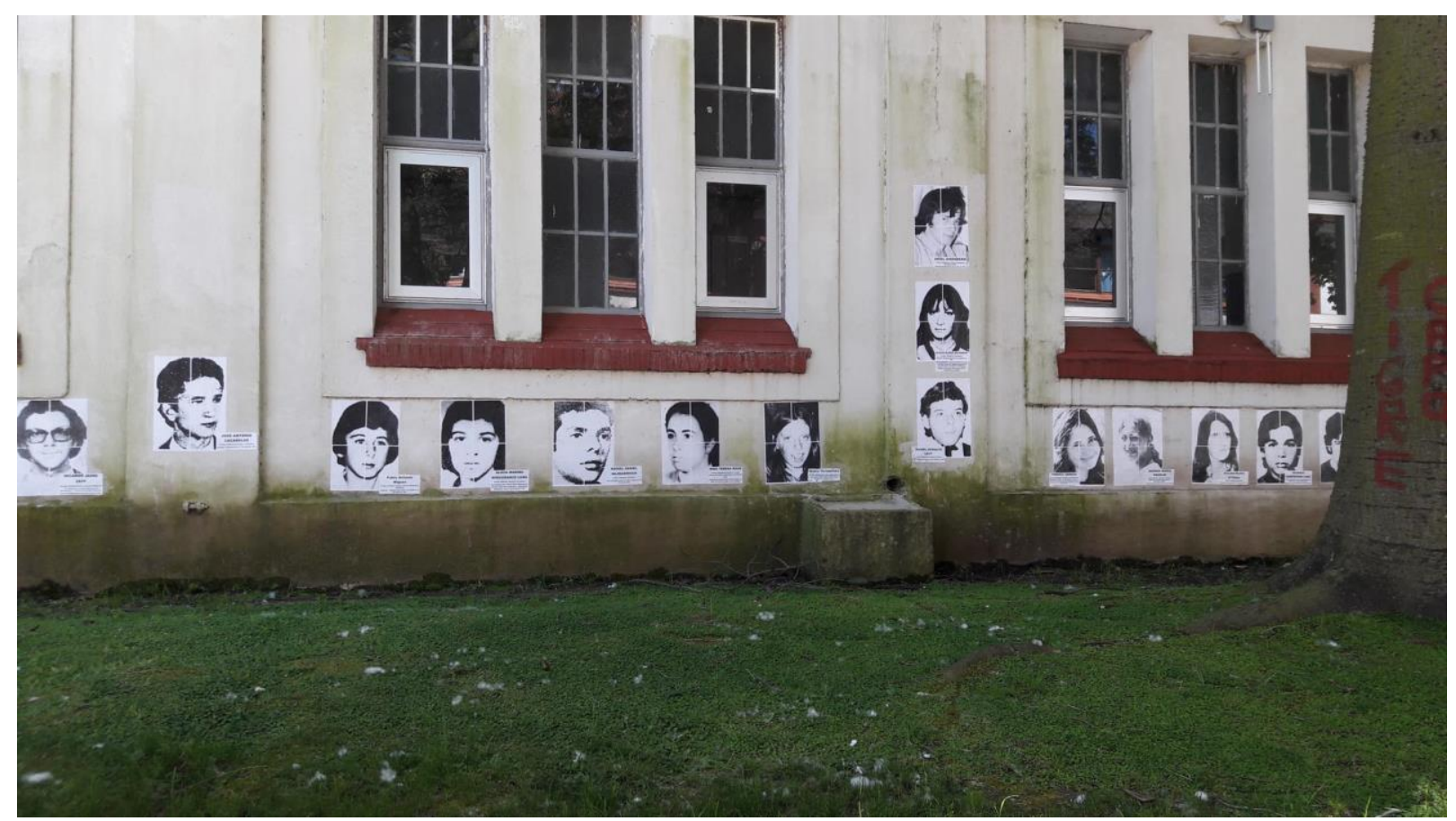

Figura 5 - Retratos de estudantes presos e desaparecidos na ESMA. Fonte: fotografia do autor, 2017.

\footnotetext{
3 Disponível em http://www.memoriaabierta.org.ar/wp/. Memoria Abierta é uma página da internet que apresenta o resultado do trabalho de várias organizações argentinas que reúnem e disponibilizam documentos de diferentes naturezas sobre as violações dos direitos humanos durante a última ditadura militar na Argentina.
} 


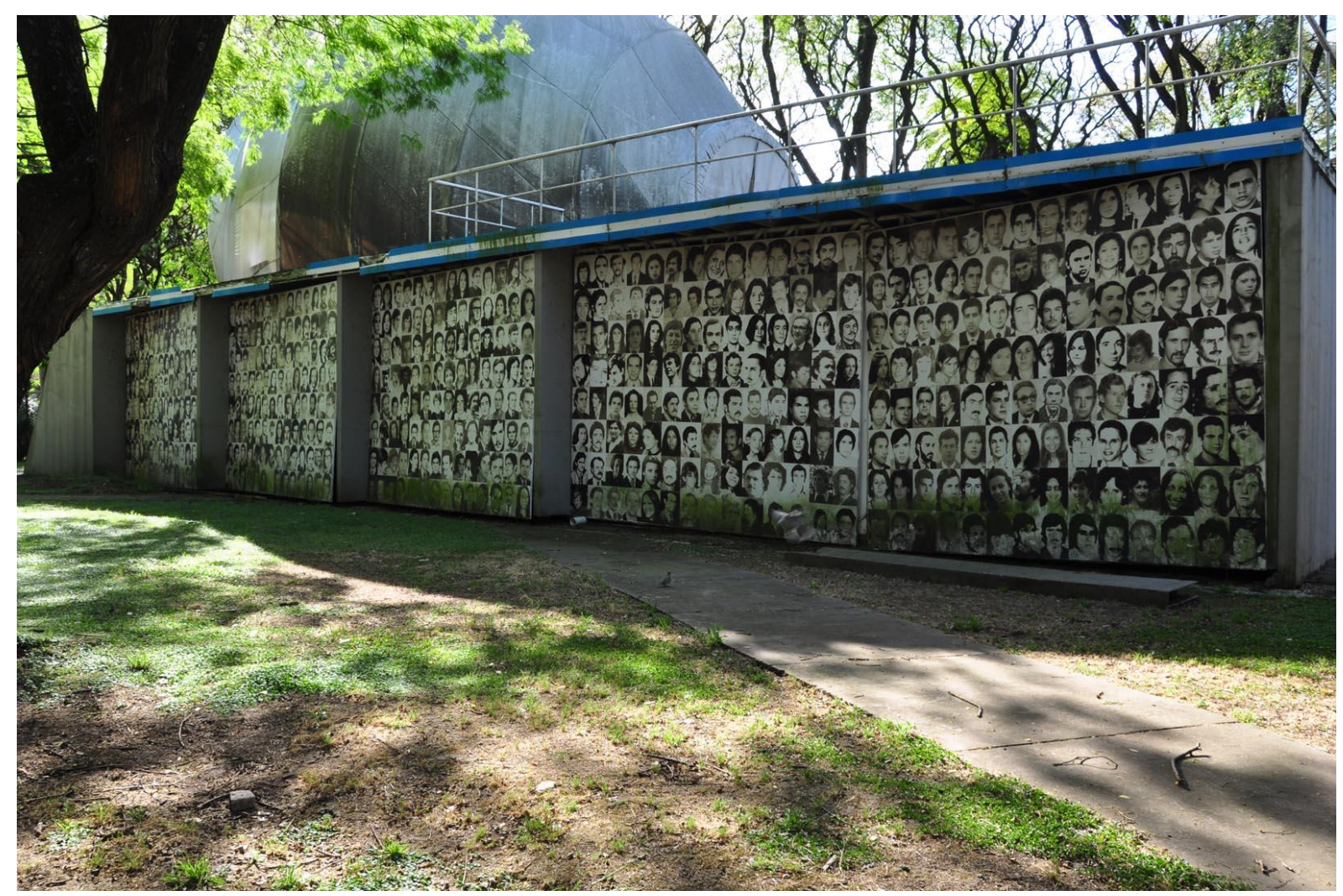

Figura 6 - Retratos das fotografias retiradas da ESMA por Victor Basterra. Fonte: Fotografia do autor, 2017.

Todos esses elementos são indícios de uma brutalidade orquestrada na violação dos direitos humanos suportada pelo Estado. As fotografias analisadas são, de modo muito intrínseco, duplos indícios: da existência do fato e da comprovação de que as pessoas estiveram lá. No entanto, o que se procura estudar é o porquê de um indício tão delével sobre a magnitude da violência é tão presente e tão intenso para a constituição desse memorial.

As desaparições ocorridas durante esse período, motivadas pelos atos violentos de uma política de austeridade e medo, hoje se fazem presentes pela imagem dos desaparecidos. As imagens, portanto, são enunciativas do desaparecimento e da história desse desaparecimento. Convergem, ambos, para o discurso de uma vida interrompida e das razões políticas que levaram a isso. O espaço expositivo imprimi, por meio da sua visualidade, um sentimento dúbio do que se vê e do que não pode ser visto, do que é e do que era, mas foi ocultado. É o sentimento imanente da presentificação da ausência. E o que faz essa operação perceptiva possível é a condição contextual da fotografia, revelada em camadas de representação simbólica.

Entende-se que a memória humana é predominantemente visual, e quando a lembrança opera, por exemplo, sobre fatos históricos, recorre-se mentalmente a imagens que os façam visíveis. Constrói-se, de tal modo, um imaginário sobre os fatos. Para imaginar, de acordo 
com (DIDI-HUBERMAN, 2004), é necessário lembrar. A história usa ferramentas para narrar fatos políticos, sendo uma delas, a fotografia.

De acordo com (CATELA, 2012), teórica na área da antropologia e autora de diversas publicações referente a assuntos relacionados à violência, situações limites, fotografia e memória, reflete sobre a trajetória e os usos das fotografias com ênfase nos retratos de desaparecidos. Algumas das imagens de desaparecidos não surgiram com o objetivo e intenção de "fazer história". Na sua origem, elas eram objetos de recordação familiar, expostas em álbuns de família ou provenientes dos documentos de identidade. Após o contexto exposto no item anterior, essas imagens passaram a ser usadas como instrumento de denúncias relacionadas à desaparição das pessoas ali retratadas.

Inauguraram, assim, uma forma diferente de protesto contra a violência intranacional. Assim, o que quis ocultar com o desaparecimento foi pouco a pouco revelado pelos retratos fotográficos de milhares de rostos que, em diversos rituais e lugares, interpelaram e interpelam o passado, o Estado, a justiça e a nação como um todo. (CATELA, 2012, p.113).

Esses retratos passaram a circular pelas ruas nas mãos de pessoas que estavam à procura de seus parentes e amigos desaparecidos e, consequentemente, aos poucos tais imagens adquiriam visibilidade nacional e internacional, sobretudo por intermédio dos meios de comunicação. Apresentar a fotografia do desaparecido passou a se constituir como uma forma de representar a desaparição (LONGONI, 2010). Num momento seguinte, a foto do desaparecido fez-se um veículo para a memória dos fatos.

\section{O indício e o intangível}

De acordo com o cientista da comunicação (Català Domènech, 2011), assim como como a pintura, a fotografia, de forma oposta, tem potencial de penetrar a realidade. Essa é a ideia que o autor emprega para diferenciar a base epistemológica que funda a representação no retrato fotográfico e pictórico. Ambos, engendrados em níveis e modos próprios de interpretação, executam o seu trabalho de aprofundamento representativo sobre o real. No entanto, a fotografia "parte da realidade de maneira mais direta" (CATALÀ DOMÈNECH, 2011, p.245). Sugere-se que, ao fazê-lo, amplia-se a sua função primária testemunhal de ingressar no plano do imaginário, no qual ela tanto é ponte entre tempos como sombras que indiciam presenças indiscerníveis.

É no âmbito dessa circunstância que as relações entre fotografia e memória se desdobram. Faz-se referência a elas para mergulhar nos sentidos que ocasionam os retratos 
das pessoas mortas ou desaparecidas durante o período político aqui estudado. São imagens que se impõem operam como elementos discursivos, que se impõem ao visitante.

Faz parte das camadas de significação de um retrato o que tal imagem vai adquirindo conforme se modifica o contexto no qual é vista. Sobre os retratos dos desaparecidos, Catela, (2012), descreve:

(...) se inicialmente eram uma simples identificação visual de alguém em um documento público, passado o tempo, à medida que a própria noção do desaparecimento foi sendo desvelada, conteúdos associados à foto, que que ampliaram seu significado e seu valor tanto simbólico como político e jurídico, emergiram. (CATELA, 2012, p.114)

Após saber sobre o ato de violência, o uso da fotografia que em sua origem retratava um cidadão e passa a retratar uma vítima da ditadura, mostra-nos um processo que, sem suplantar o evento original (a figura da pessoa), assume um novo conteúdo informativo e simbólico. Os visitantes que as encontram em seus novos contextos de significação as leem, de algum modo, sob a interpretação de uma transformação do real. Catela, (2012)

\begin{abstract}
Assim, ao longo da história do uso destas fotografias, que representam os desaparecimentos, torna-se visível o oculto e revelado o velado. Não estão em jogo somente as dimensões técnicas que provocaram mudanças e criaram diversos circuitos de consumo e apropriação; também estão envolvidas as dimensões sociais, políticas e históricas que fizeram com que estas fotografias - inicialmente usadas para registrar cidadãos em seus documentos nacionais de identidade - tenham sido eficazmente simbólicas para representá-los igualmente em sua condição oposta, a de desaparecidos, negados pelo Estado que os registrou com uma fotografia em seus DNIs. (CATELA, 2009, p.347)
\end{abstract}

As fotos, no contexto analisado, são empregadas de modo que no visitante afluem sentimentos e emoções. Operam no espaço público, simultaneamente, para denunciar e para recordar. Adquirem tanto a finalidade de (re) apresentação como a de suporte, objeto e território a partir do qual se institui o campo de lutas pelas memórias do passado recente.

Em tal contexto, em que a mesma fotografia utilizada nos documentos de identidade como prova da existência do cidadão adquiri o sentido oposto, ou seja, o de denúncia de seu desaparecimento articulam-se dois princípios contraditórios, ou complementares, em seu uso: o primeiro opera em comprovar a existência e vida do cidadão e o segundo, em indicar sua ausência ou morte.

Como dito anteriormente, parte dos retratos expostos foi produzida com o objetivo de documentar os detentos que por ali passavam. Os retratos que chegaram aos dias de hoje se devem à ação de Victor Basterra, que ali esteve aprisionado e foi um dos poucos sobreviventes. Basterra foi designado por oficiais para trabalhar no setor de documentação da ESMA. Entre suas tarefas, ele fotografava os sequestrados que por ali passavam e tinha 
acesso aos arquivos, ajudando a organizar a documentação dos detentos. Conseguiu esconder em suas roupas os negativos dos retratos que fizera. Outras vezes fazia cópias a mais e, quando saia do cativeiro, durante sua liberdade vigiada, conseguia levar o material consigo.

Tais fotografias tiveram sua primeira circulação pública em duas publicações logo após o término da ditadura, nos anos de 1984 e 1985. E desde então foram divulgadas e expostas em diversas ocasiões, com mais frequência a partir dos anos 2000, quando, por incentivo maior a políticas públicas de memória, o assunto retorna com mais força na cena pública. Desse modo, o relato de Basterra, as recorrentes exposições, as reflexões e os estudos que se foram acumulando com o passar dos anos instituíram um valor crescente para cada imagem. Como observa a autora ao analisar a relação entre o depoimento de Basterra e a exposição destas fotos: "su testimonio se fue asociando de diversos modos con esas fotos, generando múltiples sentidos y configurando de distintas maneras el trabajo memorial. ' (FELD, 2014, p.29).

A importância de uma documentação dessa natureza é que ela revela não só o fato como os mecanismos que tornavam o fato sistemático, contínuo e oculto. Fazer pessoas desaparecer sem deixar rastros sobre o modo, o lugar e os agentes imediatos desse desaparecimento implica em crime que demanda método. Quando se trata de milhares de pessoas, é de supor-se que o método exija a eliminação de toda e qualquer forma de indício.

Sobre a eliminação de rastros, é elucidativo o estudo que (DIDI-HUBERMAN, 2004) relata e analisa da sobrevivência de quatro fotografias realizadas no campo de extermínio de Auschwitz por algum membro do Sonderkomando ${ }^{4}$, que as conseguiu fazer e enviar em circunstâncias improváveis. Em seu estudo, o autor ressalta que nesse campo foi gerada uma volumosa documentação em dois laboratórios fotográficos lá instalados que processavam filmes e positivos de fotografias das execuções, das sessões de torturas, das experiências médicas da equipe de Josef Mengele ${ }^{5}$, dos retratos de identificação e das instalações do campo de concentração. A maioria das fotos e negativos foi queimada ao final da guerra, no fluxo da operação denominada "Solução Final". Tal como aconteceu com Basterra, os prisioneiros que faziam a tarefa de eliminar os documentos conseguiram salvar parte do que deveriam destruir.

As quatro fotografias que (DIDI-HUBERMAN, 2004) analisa não pertencem a esse montante, tampouco foram feitas sob demanda dos nazistas. Um ou mais dos prisioneiros que executavam as tarefas mais intoleráveis no processo de extermínio conseguiram realizar o

\footnotetext{
${ }^{4}$ Denominação dada a grupos de pessoas que atuavam ao comando nazista em campos de concentração.

5 Oficial alemão e médico que atuava durante a Segunda Guerra Mundial no campo de concentração de Auschwitz.
} 
registro de algumas cenas sobre um curto filme fotográfico e enviar o rolo para a Resistência polonesa de Cracóvia. Desse rolo, obtiveram-se quatro imagens. A tese inicial de (DIDIHUBERMAN, 2004) desenvolveu-se com foco nessas quatro fotografias. Delas, o autor desenvolve um discurso, que desenvolve em direção a uma teoria da imagem. O fundamento dessa teoria é que para saber é preciso poder imaginar. $\mathrm{O}$ autor analisa o modo como as fotografias foram feitas e levadas para fora de Auschwitz enquanto resistência ao método de eliminação de provas da existência do campo de concentração. E sem provas materiais, não se saberia do crime. Por isso, o autor as valoriza:

"Las cuatro imágenes de Birkenau son para nosotros tan preciosas porque nos ofrecen la imagen de lo humano pese a todo, la resistencia por la imagen. (...) $\mathrm{He}$ aqui porque esas fotografías nos importan, nos conciernen, nos atañen desde la situación específica de la que dan testimonio". (DIDI-HUBERMAN, 2004, p.234).

A diferença imediata entre as fotos que Basterra salva e essas feitas por anônimos do Sonderkommando é, primeiramente, no volume e, a seguir, no conteúdo. As quatro fotografias de Auschwitz documentam a condução de um grupo de mulheres para dentro da câmara de gás. As fotografias da ESMA são, os retratos dos militares que constituíam o grupo que ali atuava e que eram utilizadas para falsificar documentos (Figura 7) e os retratos dos civis, as vítimas que ali chegavam e logo eram fotografadas com intuito de documentação dos prisioneiros políticos (Figura 8) e (Figura 9). Esse conjunto representa, as fotografias que Basterra fazia clandestinamente do próprio lugar com vistas a gerar provas da existência do CCDTE.

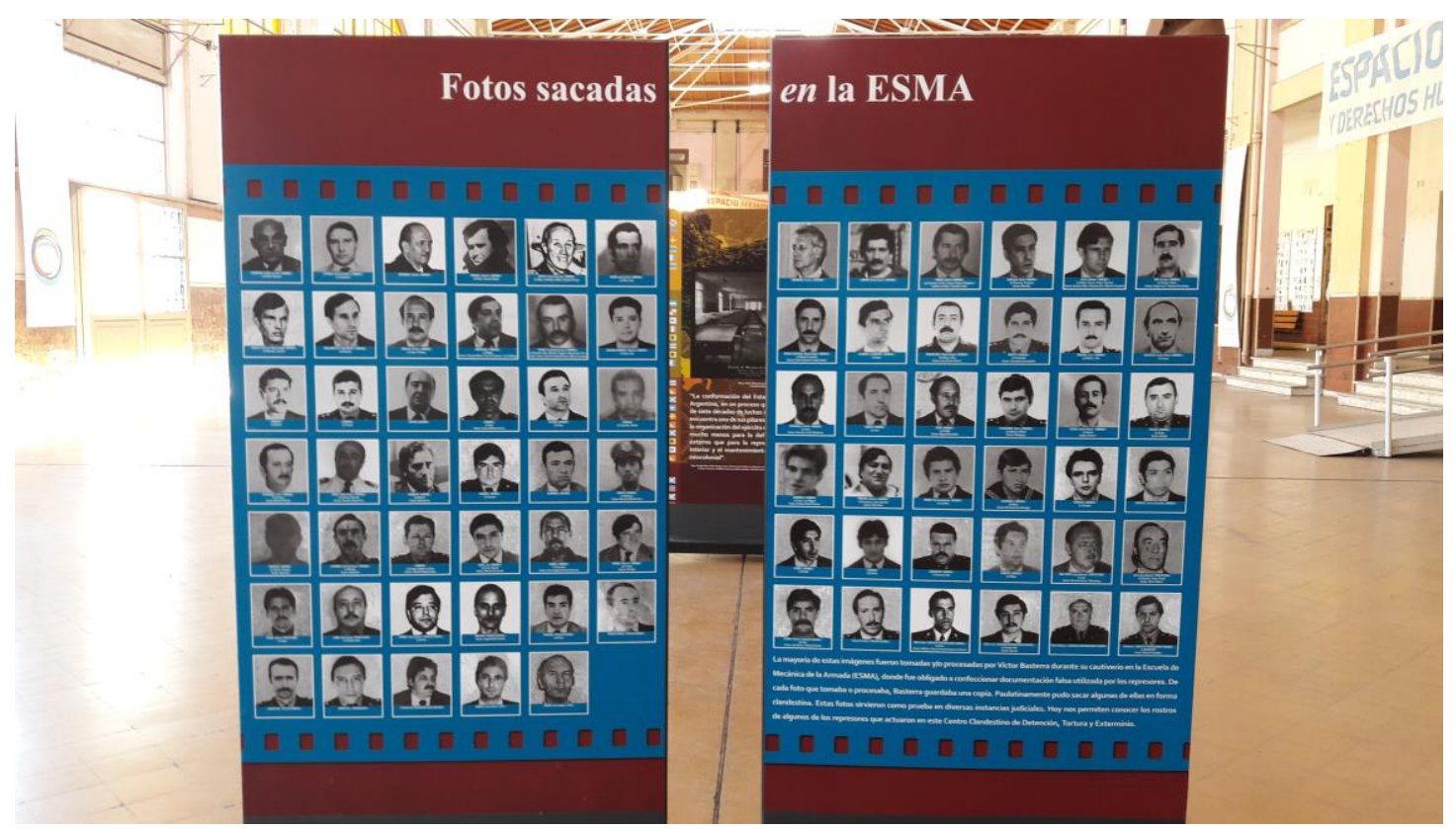

Figura 7 - Retratos de oficias militares da ESMA. Fonte: fotografia do autor, 2017. 


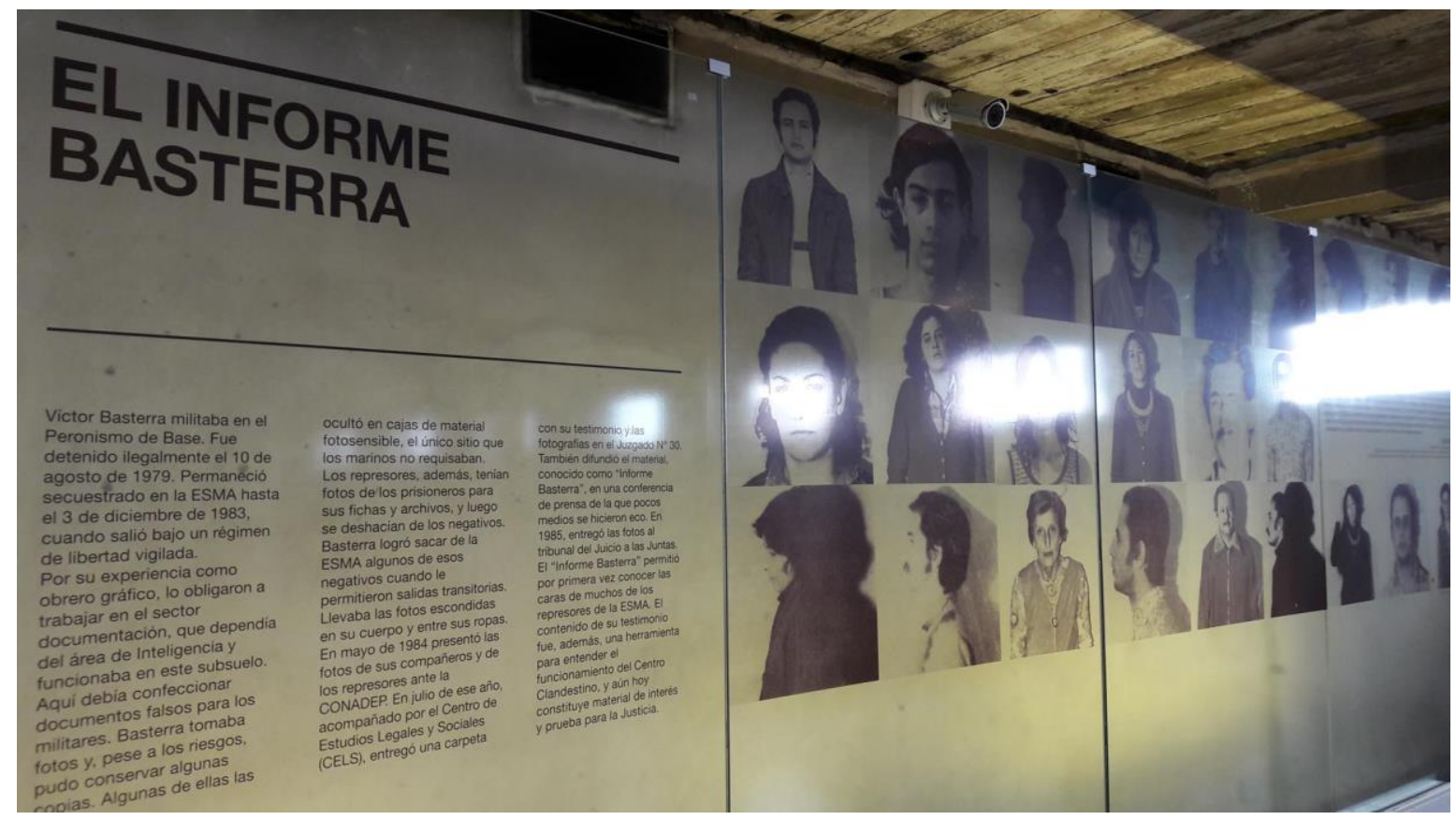

Figura 8 - Retratos de oficias militares da ESMA. Fonte: fotografia do autor, 2017.

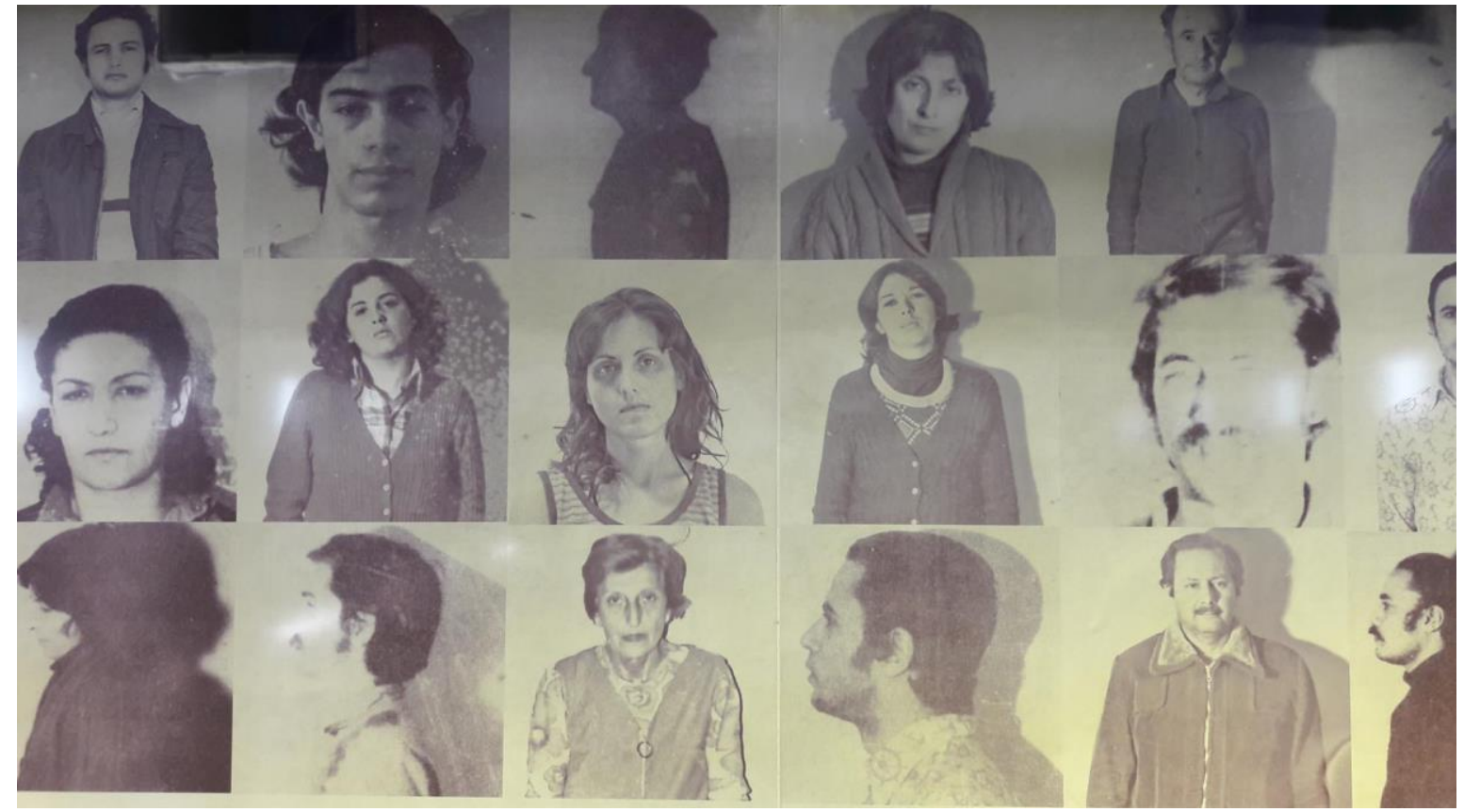

Figura 9- Detalhe do painel expositivo com fotografias de Victor Basterra. Fonte: Fotografia do autor, 2017.

As fotos do campo de extermínio são imagens que não documentam o massacre processado em Auschwitz pelos nazistas, mas que desvelam a existência do lugar. São provas que resistem ao segredo que os nazistas desejavam fazer sobre o massacre. O silenciar do fato consistia em eliminar provas e, portanto, qualquer resíduo de memória. Também as fotos de Basterra não documentam as torturas e condições do cativeiro, mas indicam a existência das pessoas desaparecidas e daqueles que as fizeram desaparecer. São os elementos que fazem da 
visita aos centros de memória da ESMA um encontro com a fantasmagoria dos injustiçados e, também, com a dos algozes. Se não valem por si, e precisam de legendas e palavras que as revistam da dor e da violência a que estão associadas, são as chaves das portas da memória que as guardam e as expõem.

\section{Considerações Finais}

O objeto desse estudo foi a imagem fotográfica, e suas representações e significações ao longo do tempo, ou seja, desde o momento de sua produção até a atualidade. As imagens na atualidade ganham um novo status, são objetos museológicos, evocadores de memórias que nas paredes e painéis ganham outros significados, diferentes dos quais as originaram. $\mathrm{Na}$ sua origem, o propósito era o de registrar, documentar, identificar o cidadão e também como elemento de recordação familiar e hoje ressurgem com outros significados e intenções. Atualmente são objetos memoriais repletos de significados, emoção e não raro a elas estão agregadas as histórias das vidas interrompidas.

Elas são, hoje, consideradas relicários com valor estético e histórico, preservadas e exibidas de diferentes formas para que não passem despercebidas. As imagens são recorrentes, muitas vezes são encontradas repetidamente em diversos locais. Estão nos arquivos e também expostas por todas as partes da ESMA. Nas fachadas e entradas dos prédios, em suas salas, corredores e janelas, estão também em painéis informativos de variados tamanhos, e também nos folhetos e livretos distribuídos. De forma simbólica, a fotografia dos desaparecidos expostas nesses lugares evoca as suas presenças e pretende o "não esquecimento". Ela faz lembrar os crimes de cunho político e clamam que jamais aconteçam novamente.

Uma vez que as imagens passam a ser abrigadas e expostas publicamente num espaço público-institucional de memória, causam impacto, despertam emoções ao espectador, remetendo a memórias coletivas vivenciadas direta ou indiretamente sobre o contexto político social que levou a cabo um programa de execução perversa de pessoas. Não são imagens para serem analisadas e descritas, são para serem sentidas. Enfim, são percepções e sentimentos que ultrapassam qualquer tipo de compreensão lógica. Quanto mais contemplamos essas imagens, mais os sentimentos e questionamentos surgem em relação ao destino das pessoas ali retratadas. Assim, seu uso na atualidade adquire a forma da ausência que se faz presente, como um eco da vida roubada e da imponderabilidade do desaparecimento. A presença desses retratos é um clamor por verdade, memória e justiça, e um sinalizador da esperança para que jamais ocorra tais violações humanas. 


\section{Referências}

BARTHES, R. A câmara clara. Nota sobre a fotografia. Rio de Janeiro: Nova Fronteira, 1984.

CATALÀ DOMÈNECH, J. M. A forma do real. São Paulo: Summus, 2011.

CATELA, L.S. "Lo invisible revelado. El uso de fotografías como (re) presentación de la desaparición de personas en Argentina". Em: Feld, Claudia y Stites Mor, Jessica (comps.); El pasado que miramos. Argentina: Paidós, 2009. p. 337-361.

- "Todos temos um retrato: indivíduo, fotografia e memória no contexto do desaparecimento de pessoas". Em: TOPOI, vol.13, nro. 24, jan.-jun 2012, pp. 111-123. Disponível em: http://www.scielo.br/pdf/topoi/v13n24/1518-3319-topoi-13-24-00111.pdf. Data da última consulta: janeiro, 2017.

DAVAllon, J. "Le muséeest-ilvraimentun média? Publics et Musées". Em: Presses Universitaires de Lyon, 1992, nro. 2: p. 99-123. Disponível em: http://www.persee.fr/doc/pumus_1164-5385_1992_num_2_1_1017. Data da última consulta: fevereiro, 2017.

DIDI-HUBERMAN, G. Imágenes pese a todo: Memoria Visual do Holocausto. Barcelona: Paidós Ibérica, 2004.

FELD, C. ¿Hacer visible la desaparición?:las fotografías de detenidos-desaparecidos de la ESMA en el testimonio de Víctor Basterra. Em: Clepsidra. Revista Interdisciplinaria de Estudios sobre Memoria, 2014 nro. 1, pp. 28-51. Disponível em: http://ppct.caicyt.gov.ar/index.php/clepsidra/article/view/FELD/pdf. Data da última consulta: março, 2017.

FERREIRA, L. MICHELON, F. Cicatrizes da Memória: fotografias de desaparecidos políticos em acervos de museus. Em: Estudos Iberos-Americanos, Porto Alegre, v. 41, nro.1, jan.-jun. 2015, pp. 79-97. Disponível em: http://revistaseletronicas.pucrs.br/ojs/index.php/iberoamericana/article/view/20716/13379.

Data da última consulta: febrero, 2017.

LONGONI, A. Fotos y siluetas: dos estrategias en la representación de los desaparecidos, Los desaparecidos en la Argentina. Memorias, representaciones e ideas (1983-2008). Buenos Aires, Argentina. Biblos, 2010. 